\title{
Gendered African (biblical) scholarship: An ode to Talitha
}

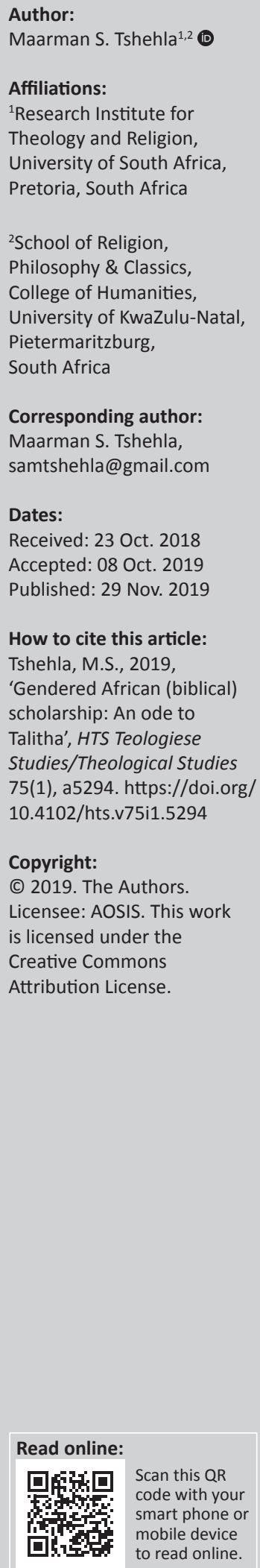

Attributed in Christian scripture to Jesus's very lips, the intriguing Aramaic phrase 'Talitha, Kum!' has emerged as an important refrain within gendered African theological scholarship. African women's experiences in the hands of religion and culture do so resonate with the two tangled stories that comprise the phrase's literary context. The resonance is such that African women's Bible reading strategies have come to be referred to as 'Talitha cum African women's biblical hermeneutics' or some variant thereof. The ensuing panegyric by a male admirer engages the fresh ways whereby African women biblical hermeneutics (aka Talitha) are breathing new life into (African) biblical scholarship. In appreciation and tribute to African women theologians' fragrant contributions to Christian life and reflection, the ode samples their work in a manner that in places feels intrusive whilst certainly nowhere near complete.

Keywords: Talitha kum; Gendered biblical hermeneutics; Circle of Concerned African women Theologians; Bible; Mark 5:21-43.

\section{Introduction: Talitha is her name}

Given how human history has unfolded hitherto, patriarchal custom and idiom are simply entrenched. Yet, and no matter how extensively repressed, women's voices and deeds have always coloured human history in intriguing and refreshing ways. His male epistemic location (Anderson 2012) notwithstanding, the present investigator explores the enthralling world of African women's biblical hermeneutics. He endeavours to appreciate African women theologians' self-understanding and insight. Professor Christina Landman's life-labour is the most immediate cause of this reflection. As one of the many spaces she claims as home, the Circle of Concerned African Women Theologians (hereinafter 'the Circle') supplies the backdrop and serves as the primary source of this exploration. Thanks to the inimitable role that the Circle has played towards gendering African theological scholarship, it is now possible to embody as 'Talitha' the otherwise multi-vocal self-expressions comprising African women's engagements with the Bible.

According to the source whence Talitha comes, the word means 'little girl' (Mk 5:41). That very literary context also gives thugatèr (daughter) as yet another loving way by which both Jairus (Mk 5:23) and Jesus (Mk 5:34) assume affirming roles over the females in their charge. In context, therefore, given Jairus' 'my little daughter' (thugatrion) plus Jesus's taking time to affirm the unclean 'daughter' who had nonetheless been so bold as to touch him, both 'girl' and 'daughter' are affectionate rather than belittling of the women concerned. The terms evoke feeling, fondness, tenderness and, in a phrase, unadulterated love towards women of all ages and life stations. This appears to be the sense in which African women are appropriating the term 'Talitha' into their critical engagements with the Bible. 'Daughter' is rather too humdrum to make its hearers stop and smell the roses; Oduyoye's Daughters of Anowa (1995) is too specific to gain widespread currency.

Exotic though it sounds to modern ears, Talitha is, in fact, an Aramaic concept with a straightforward sense. Rather than undermining its efficacy as a symbol of restoration of life, this indubitable possession of meaning rescues Talitha from the world of magical performance which the healers of Jesus' day inhabited. ${ }^{1}$ Unlike inscrutable foreign words that in the end do little more than entertain itchy ears, culturally authentic names have clear-cut referents pregnant with exciting connotations. Talitha's Zulu equivalent, Ntombazana, flows involuntarily and dotingly from the lips of African fathers during proud interactions with their daughters. Even in the plural sense,

1.Concerning the world in which Jesus of Nazareth emerged as a healer, 'a truly magical incantation most closely parallels the word power of God Himself.... As such, there are a number of distinctive stylistic features present in incantations. These can include: divine names of power, rhythm, nonsense words, foreign words, and reversals.... Akin to nonsense phrases, incantations often include nomina barbara, the use of foreign words, especially nouns/names' (Dennis 2016).

Note: The collection entitled 'Christina Landman Festschrift', sub-edited by Wessel Bentley (University of South Africa) and Victor S Molobi (University of South Africa). 
Mantombazana, used when addressing several girls or women at once, the term retains its warmth. ${ }^{2}$ Indeed, even male lovers can be heard referring to their female partners by that nickname. ${ }^{3}$ In matter of fact, Ntombi is one of South Africa's most recognisable given names. But instead of regionalising the designation, Sêti liji (Amharic), Obaa (Twi), Omobirin (Yoruba), Msichana (Swahili representing many Bantu tongues) and countless other equally doting African contenders had to give way to a non-partisan unifying term supplied by the source text.

Appropriating Talitha further promotes the culture of naming women within public discourse as well as, in the present case, acknowledging the names they give to themselves. The androcentric designations, 'Jairus' daughter' or 'woman with issue of blood', will no longer do. Moreover, Talitha may have even been the young woman's first name. As will emerge anon, Talitha thus denotes African women readers of the Bible in their unity of vision as well as in their unfathomable complexity. Talitha is private, individual, communal, complex, exclusive and inclusive, inexhaustible and ubiquitous all at the same time; she is Africa. She is 12 years old; no, she has been haemorrhaging for 12 years. She is one and she is many, young and old, naïve and experienced; she is woman. ${ }^{4}$ To take one woman seriously is to take all women seriously; the intricate character of her experience demands that it be so. Jesus simply has to make time for the one as much as for the other. It is easy, therefore, to see why this passage is so beloved of African women and indeed quite fundamental to their theologising.

The ensuing tribute listens in both sympathetically and critically as several African women engage in Talitha kum $^{5}$ hermeneutics. Publications mediated by the Circle supply adequate orientation to Talitha's general theological demeanour as it informs their appropriation of, whilst it is itself informed by, the central source text, Mark 5. Her multifaceted engagements with Mark 5 reveal a Jesus who engages women as women, as persons with valid existential concerns. The tribute reads along with Talitha; it seeks to emulate her life-giving appropriations of religious texts. It attempts to display the influence on this author of African women readings of the Bible.

2The use of 'girl' or 'little girl' as a first name (Girlie) is illustrated in the case of the late Msimang. The plural form of the name ostensibly recounts that she was preceded into the family by other girls. Her preference for 'Manto' over 'Edmie' is both ideological as well as perceptive and appreciative of the significations of her Zulu name. Those who cannot stomach her invocation can instead appreciate the forme Miss South Africa, Basetsana Khumalo, whose name is the Tswana version of Mantombazana.

3.Case in point would be the song by popular South African artist Zola entitled 'Nomhle' whose central reverb goes: ngiyak'thanda ntombazana, no matter what they say, the way this thing is going sofa s'lahlane.

4.A la Ashford and Simpson's composition, 'I'm every woman', as popularised by Chaka Khan and Whitney Houston.

5.With or without the feminising suffix (i.e. -i), cum, kum, koum and qum are acceptable transliterations of the (Hebrew) Aramaic word concerned. 'Over time, however, the Aramaic feminine singular imperative lost the ending -i... There is, however, no evidence for the change as early as the 1st cent. CE' (Horton 2009:462, sic). Because it retains mysteriousness in a way that the more equivocal cum cannot, sic). Because it retains mysteriousness in a way that the more equivocal cumc
kum suffices for present purposes (except of course in direct quotations).

\section{African women theologise: Talitha outgrows Ms Jairus}

When almost seventy African women theologians gathered in Accra, Ghana, in October 1989, and collectively resolved to construct theologies and ethics from their faith experiences and social, cultural location, their wake up call was the story of the twelve year old girl (Ms Jairus) presumed dead in Mark 5:21-43. (Njoroge 2001:247, sic)

Seventy is reminiscent of Alexandria, over two millennia ago, where the Koine Greek form of the Hebrew Bible was begotten. In Accra, 30 years ago, 70 qualified African women gave birth to gendered African biblical hermeneutics. Symbolic (rather than literalist or absolutist) interpretations rightly attend the efforts at both Alexandria and Accra. In other words, to get hung up on precise numbers - were there 70 or 72 or less or more? - and other such variables is to miss the bigger picture. Whatever else might be said about pertinent parallels and precedents, the bigger picture is that Israel's diaspora was enriched by the work carried out in Alexandria in much the same way that African theology has been enriched ever since Accra 1989 where Ms Jairus came back to life.

Mark 5:21-43, a text about two women who shared so much in common without denying obvious differences between them, proved a very competent midwife at her resurrection in Accra. With fanfare and resources nowhere near the kind provided by Ptolemy II Philadelphus at the Septuagint's birth, Ms Jairus nevertheless came to life after centuries of (African) theological scholarship presuming her dead (Oduyoye \& Kanyoro 1990). And just as early Christianity would be hard to imagine without the LXX, so too would modern African theology be pointless (i.e. blunt) without Ms Jairus' voice. She rises to add an important 'voice which has been missing in the decisions and the shaping of the African church and theology', a voice concerned rather 'deeply about the erosion and destruction of human dignity and life, all life, in Africa' (Njoroge 1997:80, emphasis added). Surely the stone the master builders once suppressed is proving to be (African) theology's saving keystone (cf. Mark 12:10).

The past three decades have seen her hard at work. Ever since summoning The Will to Arise (Oduyoye \& Kanyoro 1992), Ms Jairus has 'never gone back to sleep again' (Kanyoro 2001b:170). But the source text does not ascribe speech to Ms Jairus; she gets up, walks freely about and eats (Mk 5:42-43). For as long as her parents are in the room, alongside the four strange but named men (Mk 5:37), Ms Jairus remains a voiceless unexciting korasion (Mk 5:41-42). Korasion is the Greek rendition of the Aramaic Talitha and would surely have been as bland for Mark's audience as thugaterr. She arises, gets nourishment and sets off to meet Jesus amid and despite the thronging crowds. She encounters Jesus on her own initiative where she can exercise independent agency ('Who touched me?' , Mk 5:30). Here she finds her voice because Jesus affords her ample space (despite the crowd and its pressing needs) 
to articulate her story without condemning or rushing her (Mk 5:33). It is here where she gets to be seen as a woman and no longer a preteenager (Mk 5:42); she can now be appreciated as one who has been intimate with suffering for a duration that to a preteen amounts to an entire existence. The scope of her sorrow ranges from natural afflictions to male abusers (Mk 5:26). ${ }^{6}$ It would thus be improper to continue referring to her as 'Ms Jairus'.

As soon as she had heard about the healer named Jesus, she decides to test his authenticity by claiming her healing without permission ( $\mathrm{Mk}$ 5:27-28); to overtly seek his intervention might have meant more debt. After being made well (Mk 5:29), and having been affirmed as a daughter of the God who heals without expecting anything in return except peaceful living (Mk 5:34), she finds her voice and proceeds to tell all her truth (Mk 5:33). Being affectionately addressed as 'Daughter' by her gracious healer makes her embrace Talitha as her very own pet name. ${ }^{7}$ The tag 'Talitha' reminds her of the extent to which she is worthy of God's time and attention (Mk 5:41-43, 30-34). 'Little girl' plays into her love of attention, of doting affection, of kinship and of the innocent beauty of life; having suffered so much, she never seems capable of giving up on the brilliance that is life.

Talitha's construction of existentially significant theologies, or rather her experience of telling her own truth(s), has to be understood against the backdrop of her society's androcentricity. The problem with male privilege is that society tends to believe qualified doctors rather than their presumably ignorant victims; that man's education is predicated on excluding woman from the halls of learning is a reality often conveniently sidestepped. Masculine interests have dominated formal African theology before and after the waves of the so-called independence hit the continent from around the midpoint of the 20th century. The decisive presence of white male theologians (whether missionary or native is beside the point) in the African theological space makes it hard for many black male theologians to appreciate their advantage over against their African sisters. As a victim of foreign political and theological machinations predicated on white superiority, so goes their reasoning, how then could African culture afford the means required for oppressing others. In fact, the racially motivated bigotry witnessed in recent times across the globe further bolsters their conviction that the race question remains unresolved and, consequently, ought to retain strategic precedence over gender issues.

A cheap shot at one respected African man should sufficiently illustrate Talitha's grievance; it is a cheap shot because it is anachronistic and had his life not been cut short he might have had opportunity to evolve in some pertinent respects. Steve Biko's warning, 'Black man you are on your own', rings ever so true today as when he uttered it over four

\footnotetext{
6.latrön is masculine and plural; polla pathousa means 'she had suffered a great deal' under said many (pollōn) male doctors; dapanēsasa clarifies that her suffering had under said many (pollon) male doctors; dapanesasa clarifies that her suffering had
been, not merely somatic and physiological, but excruciatingly economically devastating as well.
}

7.Is Talitha perhaps not like the appellation 'Baby' so pervasive within modern-day love relationships? decades ago. It stands to reason that Biko was a child of his time, which is another way of saying that black 'woman' was understood to be included in his black 'man'. Yet Talitha is not completely taken in. She is unsettled especially by the masculinist outlook that renders many men unsympathetic to nature's cause. Note, for instance, Biko's equation of personhood and manhood: 'Black people under the Smuts government were oppressed but they were still men', he says, hastening to add 'But the type of black man we have today has lost his manhood' (Biko 2004:30). The manhood here implied is of the tones that Talitha finds insufferable. Androcentricity clearly goes deeper than just archaic patriarchal parlance. It is in her response to this deeper challenge that Talitha naturally distinguishes herself as peerless and no longer a mere preteen.

\section{Talitha speaks: African women and African culture}

To be sure, adds Biko, 'the black man' must acknowledge 'his complicity in the crime of allowing himself to be misused' by colonial forces (Biko 2004:31). ${ }^{8}$ But, asks Talitha, must such 'misuse' be rectified via the same domineering tactics as were used by the coloniser? ${ }^{9}$ Put differently, is humanity's way out of abuse tied to forceful forms of masculinity? Would Jesus be any different from all the other physicians who had taken advantage of the woman if he employed the same boys' club tactics that they did? Inspired by the alternative approach Jesus offers in the base text (Mk 5), Talitha resolves as follows from the word go: 'The African woman does not take the path of revenge and death, but continues to struggle for life and human dignity' (Njoroge 2001a:75). She is persuaded that in order to be an effective agent of humanity's redemption, she ought to shun the virulent path that manhood seems to connote. Dignified human life - all of life and every human being's dignity - is her primary concern.

To be sure, the African woman has stood by the black man, standing there as an unwavering support system, there 'where we are not named as individuals but as men's daughters, men's wives or mothers' (Imathiu 2001:38). She watched quietly whilst African men emerged as the continent's 'natural' spokespersons and leaders. The socalled independent Africa's history is replete with examples of how consistently African patriarchal hegemony lorded it over its own less fortunate. In a word, within religion as in broader society, the African woman was relegated to the back benches (Njoroge 2001a):

[F]or many decades the African woman was spoken for and commented on while she remained faceless and voiceless.... When African theology emerged in the 1960s, it was completely silent on women's experiences of God and their contributions to the shaping of the African church. (p. 74)

8.See discussion on Biko and complicity in Engdahi 2012:16-18.

9.Patriarchal custom's complicity saw African men happily if subconsciously emulating the colonial pyramidal perking order according to which Caucasian men occupy the zenith of human evolution, with white women vying against the males of the 'lower races' for second place, while the females of 'inferior races' must languish at the races' for second place, while the females of 'inferior races' must languish at the
bottom, purportedly with no inkling that there is more to life than the mundane bottom, purportedly with no inkling that
chores of womanhood (Griffin 1978:26). 
But she could not remain in the background forever. And when she decided to speak and to act, Talitha proceeded to put the interests of all creation above narrow partisanship. In other words, her notion of gender justice does not fall outside the framework of the struggle for the liberation of all life. This all-embracing nature - totally devoid of manhood's power delusions - also rendered her uneasy with forms of feminism that sought to settle scores by accepting as the only valid heuristic tool an exclusivist focus on gender. Salvation in its most holistic conception is the consistent premise from which Talitha's theological efforts issue. As a true custodian of life, therefore, Talitha's quest is for a (Kanyoro 2001a):

[F]uture [that] does not begin by attacking men but by finding methods of bringing [about] change together with men. This is a tall order, but it is the reality of the lived experience of African women. (p. 107)

Indeed, the grace with which she executes this tall order of redemptive labour belies the concession.

In her autobiography, Talitha gives ample details regarding her unpleasant experiences. This is attested to by the reality that the duration of her affliction is known, along with the losses incurred at the hands of multitudes of men posing as healers, as well as the very nature of her illness. This detail is not at all the result of Mark's research expertise. From very early on, African women insisted that their lived experience holds the key to their theologising, and that the telling of their lived experience calls for authentic partnerships that transcend narrow sectarian interests. 'Any authentic African theology - whether it is articulated by women or men requires meeting people in their daily lives' (Kanyoro \& Njoroge 1996:xii). Seen in this light, African theology's earlier silence on women's experiences of God and their contributions to the shaping of the African church proves to be worse than appalling. The past three decades of Talitha's activity have demonstrated beyond doubt that letting everyone in does more for society than exclusivist tendencies ever do achieve.

Fully conscious of the interwoven character of religion and culture, Talitha does not even make much of the irony that her ascendancy occurred around the time that her male counterparts had begun to display worrisome signs of intellectual fatigue (Maluleke 2001:237-238). Her African brothers were down and out as she was becoming confidently eloquent. Talitha continued to treat them with due respect and dignity, the same respect that she expects to see dished up for all of creation, herself included. She has found many culturally informed religious arguments to be nothing more than a partnership of convenience set up in order 'to explain biases, to justify actions that might otherwise be challenged, and to foster diversity at the expense of unity' (Kanyoro 2001a:103). In this connection, Talitha kum hermeneutics' 'analysis and interpretation of how culture conditions people's understanding of reality' (Kanyoro 1999:19) finds inculturation hermeneutics to be essentially an endeavour with the goal of recovering an African culture that is otherwise deaf to its own dehumanising aspects (Kanyoro 2001b:167-168). In Talitha's estimation, African inculturation theologies appear to be majoring in minors (Kanyoro 2001a):

African women theologians have argued that the cry to regain our culture is artificial, because we never lost it in the first place. The parts of culture affected were rather artificial; what actually happened was the addition of foreign cultural elements to African cultures. (p. 112)

Having successfully guarded against the foreign element of antagonism towards men, she is understandably bewildered by her brothers' eagerness to embrace agendas that pit one African against another. The problem with culture insisting that the girl is dead relates to presuming to speak on her behalf, as well as to the strain it places on her family's resources as they have to maintain a constant influx of professional and amateur mourners (Mk 5:38). However, the greatest injustice here involves the cultural-religious restrictions imposed on the girl: she is not supposed to engage in any movements that might betray the fact that there is yet life within her, neither can she be given food to eat. What is more, she must be kept in isolation, only to be commented upon by experts who alone supposedly know best that which is going on within her battered bleeding body. Ironically, this very immobility and starvation will, in the end, be the death of her, becoming as it were a self-fulfilling prophecy. That Jesus is saviour means for African women that he undoes these cultural-religious fetters designed to keep women in their place, namely, behind death's door, regardless of whether they are only coming into sexual maturity or have been embarrassingly barren for years. To put it succinctly (Oduyoye 2007):

[F]rom the raising of Jairus' daughter, Circle women remind themselves again and again that silence can be read as death; from the woman who 'touched' Jesus, Circle women have learnt to create space for themselves, even in places where traditional taboos forbid them to be. (p. 4)

Courteous though she remains, Talitha will no longer endure spaces that she experiences as asphyxiating. And, like religion and culture, sacred texts too warrant close scrutiny.

\section{Talitha speaks: African women and the Bible}

Talitha approaches the Bible (as well as Africa's other sacred texts) on terms that are in keeping with the saviour's affection towards her. She understands it concretely as 'the story of God's love relationship with humanity', which 'cannot' be appreciated 'outside the context of life' in its totality (Okure 2000:194). One does not experience God's bottomless love either selectively or prescriptively. The involved life experiences of biblical authors and the characters they chronicle, along with hearers and readers of the Bible within and across every conceivable time and space, all are valid pointers to the divine and eternal love story. In other words, experiencing God's love is what gives the Bible its significance, and the resonance of experiences 
across time and space and gender and culture is vital to this meaningfulness (Okure 2000):

Experience is the primary context for doing theology and reading the Bible. Experience is the stuff of life. Experience here is not feeling, but total [immersion] in life, being seasoned by life. (p. 202)

Speculative historical work of the sort that mainstream biblical studies tend to prize above everything else remains relevant but cannot ride roughshod over the modern Bible reader's experience of God's love in real life. Hence, for instance, hearing Jesus rebuke Martha for keeping busy whilst praising Mary for pursuing discipleship (Lk 10:38-42) proves a hard pill to swallow. 'Hospitality and service are the true hope for the starving and dying millions' of Africa, and so, 'for us, celebrating Mary's privileged position of learning is very painful' (Kanyoro 2001a:108). Immersion in African life requires that the distinction made by Jesus in Luke 10 is seen as a lapse into masculinist dualism. Talitha's biblical hermeneutics does not take kindly to sectarianism, sexism, favouritism or bias of any kind regardless of where it originates. Simplistic binaries simply will not do. And trained scribes of God's Kingdom thrive on balance $(\mathrm{Mt}$ 13:52's the new as well as the old; Matthew 23:23's the former without neglecting the latter). In a word, African women are profoundly shaped by 'the genuine experiences of communal living in Africa' (Kanyoro 2002:38); they do not suffer the need to posit an 'Other' against whom to stand or speak.

She hears the saviour loud and clear. She clings to his words, and therein finds not just solace but a language for expressing her own life experiences in ways that make sense to her. The fluid array that is her 'biblical reading strategies' issues out of being completely taken in with this exhilarating (Dube 2012):

$[A] \mathrm{rt}$ of living in the resurrection space; the art of continually rising against the powers of death - the powers of patriarchy, the powers of colonial oppression and exploitation, the powers that produce and perpetuate poverty, disease and all forms of exclusion and dehumanisation. (p. 34)

Talitha kum hermeneutics revolves actively around ensuring that during engagements with the Bible or any other sacred text, 'gender oppression is highlighted, and new visions of the world are advanced' (Dube 2001a:21). Africa's deplorable conditions have coerced Talitha to seek ways through which to accommodate as well as intellectually benefit from associating with even those of her sisters who 'cannot read and write but they sing, they dance and they speak' (Kanyoro 2001b:175). For Talitha, immersion in life thus actualises 'no opposition between being academic and working at the grassroots' (Oduyoye \& Kanyoro 1992:15). The result of this far-reaching sisterhood has been the 'inspiring number of articles, books, performances and practices' that undeniably validate Talitha's resurrection (Dube 2012:35). As advanced biblical disciplines do not enjoy high subscription numbers irrespective of gender, Talitha boasted at the close of the second decade following her resurrection, 'not more than ten formally certified African women biblical scholars' (Oduyoye 2007:6).
Whilst one hopes that the number has more than doubled at the onset of the fourth decade, one must also valorise Talitha's undermining of the discipline's detachment from the masses who consume the Bible on daily basis. The few qualified African biblical scholars have to constantly swat off distracting establishment critics who are given to pointing out how far off the well-trodden hermeneutical paths they are veering. Thankfully, however, Talitha will not cogitate as though she were an island. On the one hand, she regularly reminds herself that the Bible is only one of the arrays of implements at her disposal, just another tool in need of creative appropriations. 'The biblical texts are but a fraction of human testimonies of grappling with living the God-given life' (Dube 2012:42). As a result, and despite being proficient therein, gendered African Bible readers cannot implicitly subject life under that 'elitism, patriarchy, and Eurocentrism' so characteristic of that overconfident endeavour which purports to be 'critical', that is, 'objective, value-free, and rational' biblical scholarship (Imathiu 2001:2). Immersion in life, or the art of living in the resurrection space, takes precedence.

On the other hand, Talitha appropriates biblical stories in community and for their transformative, nurturing and lifepromoting capacities. She creatively re-tells (as opposed to merely 'rote-reciting') biblical narratives in a manner that facilitates freedom for the oppressed, the voiceless, the unnamed, the female characters of both ancient and modern times. And out of this solidarity emerges a realisation, an appreciation of the mystery that, contrary to what religious tradition would have women believe, the Bible presents 'Christ [as] truly woman, yet truly divine' (Amoah \& Oduyoye 1988:44). Inspired by the Jesus encountered in Mark 5, Talitha is thus able to confidently describe the contours of her relationship with the Bible in the most pragmatic of terms (Dube 2012):

Talitha cum African women's hermeneutics is therefore the practice of living daily in confrontation with international oppression of the past and present; gender oppression of the past and present; physical wounds of the past and present: a confrontation of sickness and death, which must give way to healing. (p. 36)

\section{Talitha is not complacent: African women and criticality}

To place traditional biblical methods at the service of life as she experiences it is not the same as shutting out criticism. However, she is quite upfront about engaging in brutal selfintrospection, or 'internal stock-taking', which must always be 'coupled with an invitation to objective external review of our work' (Phiri 2005:40). Just as Nicodemus could not resist Jesus (Jn 3:2), male African theologians cannot ignore Talitha's ever-growing 'profound influence on academic reflections in the discipline of theology' (Fiedler \& Hofmyer 2011:40). Surely the growing number of African men who are appreciating, engaging or even seeking tutelage at Talitha's feet is an encouraging sign. From Talitha kum hermeneutics, the African Nicodemus encounters persons who speak about 
what they know (Jn 3:11-12). Several able scholars have undertaken such critical engagement of Talitha kum biblical hermeneutics; they include inter alia Maluleke (1997), Pemberton (2003), Monohan (2004), Pui-lan (2004), Chitando (2009), Fiedler (2010), Maponda (2016), Togarasei (2016), Farisani (2017) and Mbuvi (2017).

So far as self-criticism goes, Christina Landman provides an excellent window into Talitha's soul. She embodies several worlds that must vie for Talitha's attention if she is to be all things to all people. Landman is a white South African with two theological doctorates, neither of which is in Biblical Studies even though she had excelled in postgraduate Greek and ancient Christian writings (Plaatjies van Huffel 2014:66). Her race arises because - if Denise Ackermann's edgy liminality within the Circle is instructive - a white South African woman at times feels 'left out' whilst at other times she flatly refuses to identify with some of the experiences and 'traditions of indigenous African people' (Kanyoro 2001a:103-104). Landman herself alludes to this tension when she recalls her observation of that 'unfortunate dichotomy' amongst South African women which ensured that 'those women... with acute insight into societal suffering were black, whilst the few women with theological training were white' (Landman 1996:101). This has been her lived experience of labouring in critical solidarity with her fellowAfrican sisters, especially in the context of communal Bible study. ${ }^{10}$ How then does she bring her unique socio-epistemic position to bear on Talitha's interpretive strategies?

As the luxury of formal education is scarcely available to many African women, Bible studies mediate spaces where African women biblical scholars, few as they are, can enrich their sisters in regard to background and text-critical matters. Bible studies also provide safe spaces where praxis can threaten the patriarchal leanings that may have crept in during Talitha's formal training and/or throughout a lifetime of exposure to patriarchal biblical commentary. In a nutshell, at Bible study women 'can be educated theologically; conscientised as to their human dignity' as well as 'obtain insight into their own situations by learning from the everyday problems of women in the Bible' (Landman 1996:99). In the face of centuries-old layers of patriarchal interpretations, consciously contextual and unapologetically gendered Bible studies surely play the important role of affirming 'women's agency as full human beings' (Oduyoye 2007:6). That is so because during Bible study, it becomes possible 'to interpret the lives of the women in the Bible as allegories' of present-day women's life experiences. Those 'working within historical criticism' need to increasingly accept the fact that the 'allegorical approach... opens up more narrative possibilities than does historical criticism in its basic form' (Landman 1996:100). In Paul's pastoral turn of phrase, 'These things happened to them to serve as an example, and they were written down to instruct us, on whom the ends of the ages have come' (1 Cor 10:11).

10.'When we African women cry for inclusion and participation we cannot at the same time opt for struggle by and for individuals. Our success depends entirely on our ability to make our theology a communal theology' (Kanyoro 2001b:175)
Nonetheless, the pressure to show how Talitha's hermeneutical manoeuvres measure up persists and manifests rather vividly in Landman's 2001 contribution to the Circle's growing tome. Landman heeds expert mourners' lamentations. Without locking them outside of the operating theatre where life is being restored, Landman (2001) gets distracted and shifts from her earlier position (indicated above). In this way, she confirms the truism that the prioritisation of hermeneutical tools in the excavation of 'the meaning of a text is influenced by the culture, experience and values of the person reading it and the application to which it is put' (Oduyoye 2007:5). When she asks, of what concrete use are 'women in the Bible' for 'their twentieth century sisters' (Landman 2001:83), Landman appears to be yielding to the already acknowledged lack of acute insight into societal suffering compounded by advanced (read 'detached') theological training. She goes on to urge the creation of some real and unsettling critical distance between women mentioned in the Bible on the one hand and modern (African) women on the other hand, all this needing to be done despite the reality of their shared experience of oppression (Landman 2001:84).

This momentous shift from the earlier stance in favour of allegorisation arises because African women's biblical hermeneutics tends to rather simplistically adopt biblical characters and perspectives. There is cause for caution, an imperative for the ends to not baptise the means without adequate critical distance. Easy co-identification with biblical women is untenable for several reasons, including the following:

1. Mediators (presenters) of biblical women did not accord full human status to their women; as a result, biblical women 'can only be used as negative sources to demonstrate the lack of human dignity and visibility with which these women were treated in their societies' (Landman 2001:83). Much to Landman's consternation, Talitha kum hermeneutics tends to give women of the Bible more credit than they are due.

2. As represented, Bible women do not display 'consciousness' of their religious and cultural oppression; they appear contented to only make of their patriarchal world the best that they can (Landman 2001:84). Granted, they are presented by prejudiced male authors; still, modern (African) women readers of the Bible must beware the trap of emulating precisely this characterisation of biblical women. It is sometimes easy for the reader to uncritically adopt the writer's perspective. Remembering that the women who sought to challenge the status quo have by and large been excised from the Bible should keep Talitha suspicious of those who made it in (Landman 2001:86). In other words, the official canon's overall value vis-à-vis women's emancipation is not what it is often presumed to be.

3. Emphasising the Bible's positive role models - with which modern middle class (educated) women tend far more easily to identify - runs the risk of creating the unfortunate impression that the societies of biblical times were more inclusive and gender-sensitive than was in 
fact the case (cf. Maluleke 2001:244-245) or that women from biblical times were far more emancipated than their modern counterparts. In other words, it is vital for Talitha to always keep in mind that, in their day, Esther and Ruth and Mary Magdalene were the exception rather than the rule.

4. Flowing from the foregoing consideration, there is need to recognise women's diversity now but equally during Bible times. It suits patriarchy to be able to make sweeping statements about women (Landman 2001:85-86). No sane person lives their life consciously meaning to consistently represent the gender or class to which she belongs. Individuality is very much a part of being human. Talitha's theological and hermeneutic contribution therefore lies in the interactions and exchanges that occur when women reflect together ('theology of relations'), including in their interactions with men and nature ('theology of interrelatedness'). To posit a monolithic Eve who represents all women of Africa, or of the Bible, or of all time, is simply counterproductive (Landman 2001:89-90).

Once awareness obtains of how different modern worlds are from ancient ones (critical distance), of how biblical and extrabiblical women represent androcentric society's aspirations and interests more than they represent a class or gender (individuality), of how unnecessary it is to oversimplify women's experiences (stereotyping) in order to make even a valid point, only then may Talitha engage modern and ancient 'cultures in order to criticise what is oppressive and to develop what is liberative in African customs' (Landman 2001:90). Whilst historical critics are allergic to the unproblematic transfer of Biblical contents to present contexts' (unproblematic here stands for 'uncritical', selectively 'literalist', 'anecdotal', 'fundamentalist', and so forth), they will nevertheless countenance this embarrassingly naïve appropriation of biblical texts in situations where ideologically compatible benefits are likely to accrue, that is, in situations where their own approach is either too cumbersome or just plain incompetent. In the case of HIV and AIDS, 'discourses of shame and stigma', for instance (Landman 2014):

However, the aim of using fundamentalism as a method to form a foundation for current societal values that counteract practices of stigmatisation and indifference, based on the values of the first Christians who challenged the culture of an insensitive and cruel society, is here assessed as a responsible - albeit fundamentalist use of the Bible. Anew language, albeit in line with fundamentalist practices, is being formed for churches that are competent to deal with people living with HIV in order to construct new discourses that will undermine present discourses of shame and stigma. (pp. 2-3)

In this quest, and away from the constricting over-textuality so essential to historical critical approaches, African women theologians find that this engagement occurs best at the level of story. As the retelling of Mark 5 story has illustrated herein, 'stories told and retold in such a way that women (and men) today can make some contextual identifications with [Bible women] in terms of relations, inter-relatedness and social practice' (Landman 2001:90).

\section{Precis: Talitha's is a story of faith in God}

The child's mother being in theatre with them (Mk 5:40) helps balance things out; women of different generations are required in this restorative effort. Jairus 'fades in importance, leaving the two ['three' if the mother is included] nameless female characters' on the centre stage (Duran 2008):

The drama of healing, death, and life is played out between the bleeding woman and the dying daughter, with Jesus as mediator.... The coincidence of the woman's healing and the daughter's death seems to imply that the daughter's life was the price for the woman's healing. However, with Jairus, we are implored 'only believe', and we find that in fact, one woman's death need not be the price of another's renewed life. (p. 183)

True faith repels fear. Fear has consumed men for centuries; fear of plunging into lack, of running out of life's comforts or limited resources, the fear of being exposed as inadequate, that is, unable to look after those who are under our care. Driven by fear of lack, men have infected humanity's consciousness with a malevolent sperm, which manifests over and over again as needless wars and man-made plagues. Lack of faith would be the reason behind sister turning against sister in the name of limited places at the master's table! Fear stands behind the tragic stories we constantly hear involving men who take their own lives along with the lives of their nearest and dearest. The seemingly interruptive and unplanned healing of the bloodied woman on the way does not at all threaten Jairus' daughter's healing! On the contrary, it should bolster his resolve in relation to the agency of faith in action. One who believes is not held back by fear; she acts even whilst knowing full well that her action risks incurring men's ire because it snubs cultural and religious norms and expectations.

The instruction to jettison fear is apt because culture and religion rely on fear to recruit and retain adherents. One cannot always draw the line between shame, taboos, curses, rites of passage, and eternal damnation. For this reason, the Circle prioritises the following main areas of focus (Kanyoro 2001b:170): (a) cultural and biblical hermeneutics, (b) women in culture and religion, (c) history of women, as well as (d) ministries and theological education and formation. The present exercise has been concerned with only the first of these important foci, whose very christening - cultural and biblical hermeneutics - already hints at gendered African theology's conviction that sacred texts are always culturally mediated. Life experiences are manifold as illustrated above, but culture is the fertile ground wherein both life and death flourish to degrees that depend on the stewardship at hand.

Culturally informed people know what death looks and smells like; they know how to behave when death has struck one of their own. Different roles apply to society's men and women whether they are themselves bereaved or they ought only to comfort the bereaved. Adult members of African societies are aware of the various 'rituals, taboos, initiations 
that accompany birthing, growing up, marriage, mothering, death; ceremonies to celebrate those occasions; and practices and precautions to ensure a future' along with their de facto connections to 'naming rituals, fertility, dowry, property, ownership, widowhood, sexuality, polygamy' (Kanyoro 2001a:103). Whilst the home of the bereaved is not a place for wanton laughter, ridiculous suggestions like 'The girl is only asleep' (Mk 5:39) can only generate hysteria (Mk 5:40). Furthermore, the esteemed leader of the synagogue should not ignore the fact that contact with a corpse is defiling. Is he also not making much of the fact that he witnessed Jesus being touched by a haemorrhaging woman?

Whilst speaking of African women's hermeneutics in straightforward terms, the foregoing presentation has indicated inter alia that Talitha's appropriations of the Bible are neither monolithic nor consistent. Human beings are much more pragmatic than they are generally prepared to concede. Neither life, gender, religion no human experience comes cut and dried. That is precisely the weakness of male theologies over the centuries. Paradox and ambiguity, randomness and caprice, these and many other untameable qualities give life its capacity to be exciting and uplifting, as well oppressing and distressing. There is no pressure to reach a final verdict once and for all; there is only the pressure to arise and act in life-promoting ways.

In sum, like stories of the Bible's female characters, the stories of African women readers of the Bible are imbued with bold subversions (e.g. an unclean woman with nothing to lose touches a holy man; the holy man touches a deceased thus unclean - body), startling reversals (a kinless woman gains new identity as Jesus' 'daughter' through her own faith; a dead girl regains life), displays of faith or lack thereof ('if I may only touch...' versus commotion, weeping, laughter and amazement), pregnant parallels and symbolisms (liminality represented by 12 years; the girl having been born when the woman's illness began), striking conventionalities (in order to count, the women require some male figure's covering; this includes Jairus' wife), etc. Talitha draws on this inexhaustible treasure for her sustenance, even though at times she may appear to be a fussy eater. When all is said and done (Dube 2001a):

[T] he story in Mark 5:21-43 offers a model of transforming power, which calls for the involvement of the powerless and the powerful. It is a model that involves reaching out to touch and being touched. It suggests that the powerful and the powerless must work together to redistribute power. (p. 6)

\section{Acknowledgements Competing interests}

The author declares that he has no financial or personal relationships that may have inappropriately influenced him in writing this article.

\section{Author's contributions}

M.S.T. is the sole author of this research article.

\section{Ethical considerations}

This article followed all ethical standards for a research without direct contact with human or animal subjects.

\section{Funding information}

This research received no specific grant from any funding agency in the public, commercial or not-for-profit sectors.

\section{Data availability statement}

Data sharing is not applicable to this article as no new data were created or analysed in this study.

\section{Disclaimer}

The views and opinions expressed in this article are those of the author and do not necessarily reflect the official policy or position of any affiliated agency of the author.

\section{References}

Amoah, E. \& Oduyoye, M.A., 1988, 'The Christ for African Women', in M.A. Oduyoye $\&$ V. Fabella (eds.), pp. 35-46, With passion and compassion: Third world women doing theology, Orbis, Maryknoll, NY.

Anderson, P.S., 2012, Re-visioning gender in philosophy of religion: Reason, love, and epistemic locatedness, Taylor Francis.

Biko, S.B., 2004, I write what I like, Picador, Johannesburg.

Chitando, E., 2009, Troubled but not destroyed, World Council of Churches, Geneva.

Dennis, G.W., 2016, The Encyclopaedia of Jewish Myth, Magic and Mysticism, 2nd edn., revised, expanded \& illustrated, Llewellyn Publications.

Dube, M.W., 2001a, 'Little girl, get up: An introduction', in N.J. Njoroge \& M.W. Dube (eds.), Talitha Cum! Theologies of African Women, pp. 3-24, Cluster, Pietermaritzburg.

Dube, M.W., 2001b, 'Introduction', in M.W. Dube (ed.), Other ways of reading: African Women and the Bible, pp. 1-19, SBL, Atlanta, GA.

Dube, M.W., 2012, 'Talitha Cum Hermeneutics of liberation: Some African women's ways of reading the Bible', in M.W. Dube, A.M. Mbuvi \& D.R. Mbuwayesango (eds.), Postcolonial perspectives in African Biblical interpretations, pp. 29-42, SBL, (eds.), Postcolo

Duran, N.W., 2008, 'Jairus', in K.D. Sakenfeld (ed.), The New Interpreter's Dictionary of the Bible, Vol. 3, pp. 182-183, Abingdon, Nashville, TN.

Engdahl, H., 2012, 'Theology as politics in Afrikaner Nationalism and Black Consciousness. A close reading of FJM Potgieter and Steve Biko', Journal of Theology for Southern Africa 144, 4-25.

Farisani, E.B., 2017, 'Current trends and patterns in African Biblical Hermeneutics in post-Apartheid south Africa: Myth or fact?', Scriptura 116(1), 1-20.

Fiedler, R.N., 2010, 'The Circle of Concerned African Women Theologians: History and theology (1989-2007)', Unpublished PhD thesis, University of the Free State.

Fiedler, R.N. \& Hofmyer, J.W., 2011, 'The conception of the Circle of Concerned African Women Theologians: Is it African or Western?' Acta Theologica 31(1), 39-57. https://doi.org/10.4314/actat.v31i1.3

Griffin, S., 1978, Woman and Nature: The roaring inside her, Harper Colophon, New York.

Horton, F.L., 2009, 'Talitha Cumi', in The New Interpreter's Dictionary of the Bible, vol. 5, p. 462, Abingdon, Nashville, TN.

Imathiu, G.R., 2001, 'Reading between the Lunes: Power, representation and Luke's Acts', in N.J. Njoroge \& M.W. Dube (eds.), Talitha Cum! Theologies of African Women, pp. 27-39, Cluster, Pietermaritzburg.

Kanyoro, M.R.A., 1999, 'Reading the Bible form an African Perspective', The Ecumenical Review 51(1), 18-24. https://doi.org/10.1111/j.1758-6623.1999.tb00375.x

Kanyoro, M.R.A., 2001a, 'Cultural Hermeneutics: An African contribution', in M.W Dube (ed.), Other ways of reading: African women and the Bible, pp. 101-113, SBL, Atlanta, GA.

Kanyoro, M.R.A., 2001b, 'Engendered Communal Theology: African women's contribution to theology in the 21 st century', in N.J. Njoroge \& M.W. Dube (eds.), Talitha Cum! Theologies of African Women, pp. 158-180, Cluster, Pietermaritzburg

Kanyoro, M.R.A., 2002, Introducing feminist cultural Hermeneutics: An African perspective, Sheffield Academic Press, Sheffield.

Kanyoro, M.R.A. \& Njoroge, N.J., 1996, 'Introduction', in M.R.A. Kanyoro \& K. Njoroge (eds.), Groaning in faith: African women in the household of God, pp. xii-xv, Acton, Nairobi. 
Landman, C., 1996, 'A land flowing with milk and honey: Reading the Bible with women who are breastfeeding', in M.R.A. Kanyoro \& K. Njoroge (eds.), Groaning in faith: African women in the household of God, pp. 99-111, Acton, Nairobi.

Landman, C., 2001, 'The implementation of Biblical Hermeneutics', in N.J. Njoroge \& M.W. Dube (eds.), Talitha Cum! Theologies of African Women, pp. 83-93, Cluster, Pietermaritzburg.

Landman, C., 2014, 'The church as a HIV-competent faith community: An assessment of Christian AIDS Bureau for Southern Africa's Churches, Channels of Hope training', Verbum et Ecclesia 35(2), \#1348. https://doi.org/10.4102/ ve.v35i2.1348

Maluleke, T.S., 1997, 'Half a century of African Christian theologies: Elements of the emerging agenda for the twenty-first century', Journal of Theology for Southern Africa $99,4-23$.

Maluleke, T.S., 2001, 'African "Ruths," Ruthless Africas: Reflections of an African Modercai', in M.W. Dube (ed.), Other ways of reading: African Women and the Bible, pp. 237-251, SBL, Atlanta, GA.

Maponda, A.M., 2016, 'The impact of the Circle of Concerned African Women Theologians: French zone on church and African theology issues', Verbum et Ecclesia 37(2), a1597. https://doi.org/10.4102/ve.v37i2.1597

Mbuvi, A.M., 2017, 'African Biblical studies: An introduction to an emerging discipline', Currents in Biblical Research 15(2), 149-178. https://doi.org/10.1177/1476993X 16648813

Monohan, B.M., 2004, Writing, sharing, doing: The Circle of Concerned African Women Theologians, Electronic thesis, Boston College, University of Boston.

Njoroge, N.J., 1997, 'The missing voice: African women doing theology', Journal of Theology for Southern Africa 99, 77-83.

Njoroge, N.J. 2001a, 'A spirituality of resistance and transformation', in N.J. Njoroge \& M.W. Dube (eds.), Talitha Cum! Theologies of African Women, pp. 66-82, Cluster, Pietermaritzburg.
Njoroge, N.J., 2001b, 'Talitha Cum! to the New Millennium: A conclusion', in N.J. Njoroge \& M.W. Dube (eds.), Talitha Cum! Theologies of African Women, pp. 245-259, Cluster, Pietermaritzburg.

Oduyoye, M.A., 1995, Daughters of Anowa: African Women and Patriarchy, Orbis, Maryknoll, NY.

Oduyoye, M.A., 2007, 'Re-reading the Bible from where we have been placed: African women's voices on some Biblical texts', Journal of African Christian Thought 10(2), 3-7.

Oduyoye, M.A. \& Kanyoro, M.R.A. (eds.), 1990, Talitha Qumi, Proceedings of the Convocation of African Women Theologians, Daystar, Ibadan.

Oduyoye, M.A. \& Kanyoro M.R.A. (eds.), 1992 The will to arise: Women, tradition and church in Africa, Orbis, New York.

Okure, T., 2000, 'First was the life, not the book', in T. Okure (ed.), To cast fire upon the Earth: Bible and mission in today's multicultural global context, pp. 194-214, Cluster, Pietermaritzburg.

Pemberton, C., 2003, Circle thinking: African Women Theologians in dialogue with the west, Brill, Leiden.

Phiri, I.A., 2005, 'The Circle of Concerned African Women Theologians: Its contribution to ecumenical formation', The Ecumenical Review 57(1), 34-41. https://doi. org/10.1111/j.1758-6623.2005.tb00216.x

Plaatjies van Huffel, M-A., 2014, 'The remarkable career of Christina Landman, pioneer feminist theologian rooted in the reformed tradition', Studia Historiae Ecclesiasticae 40 (Supplement), 65-83.

Pui-lan, K., 2004, 'Mercy Amba Oduyoye and African women's theology', Journal of Feminist Studies in Religion 20(1), 3-20.

Togarasei, L., 2016, 'The legacy of circle women's engagement with the Bible: Reflections from an African male biblical scholar', Verbum et Ecclesia 37(3), a1582. https://doi.org/10.4102/ve.v37i2.1582 